\title{
EVALUATION OF EGOVERNMENT AND GOOD GOVERNANCE DEVELOPMENT IN EU MEMBER COUNTRIES
}

\author{
Eva Ardielli ${ }^{1}$; Roman Vavrek $^{2}$ \\ ${ }^{1}$ VSB - Technical University of Ostrava, Faculty of Economics, \\ Sokolská 33, 70200 Ostrava, Czech Republic \\ ${ }^{2}$ University of Prešov, Faculty of Management \\ 17. Novembra 15, 08001 Prešov, Slovakia \\ e-mail: ${ }^{1}$ eva.ardielli@vsb.cz; ${ }^{2}$ roman.vavrek@unipo.sk
}

\begin{abstract}
Good Governance is a contemporary trend in public administration worldwide. It emphasizes efficiency, openness and transparency in the management of public affairs. An important factor of Good Governance is the application of ICT in public administration and the expansion of eGovernment, as a progressive element of the modernization of public administration. The presented article is focused on the evaluation of the interdependence between eGovernment and the development of Good Governance in the European Union (EU) countries. The interdependence of variables is examined based on the results of eGovernment evaluation model using multicriterial decision-making (MCDM) methods (TOPSIS method) and the values of WGI index monitored and processed by the World Bank. Based on the use of correlation and regression analysis, the interdependency between eGovernment and Good Governance development in EU member countries was confirmed.
\end{abstract}

\section{Keywords}

E-government; European Union; Evaluation; Good governance; Public administration.

\section{Introduction}

As stated by [11], [14] and [42], eGovernment is one of the priority modernization trends of public administration in the EU member states. eTools help to ensure more efficient government service delivery and sharing information, to eliminate obsolete hierarchical and bureaucratic structures, to support customer orientation and to increase transparency and accountability in public sector.

General definition of eGovernment is broad and divergent. United Nations [36] describes eGovernment as the use of information and communication technologies (ICT) in a way of government transformation for the purpose of increasing availability, effectiveness and accountability. eGovernment promotes and improves broad stakeholders' contribution to national and community development, and deepens the governance process as well [3]. As stated by [23], in accordance to the trend of cost savings in the public sector, eGovernment became one of the possible options how to operate more efficiently, effectively and transparently, to provide better, cheaper and faster services and open data to the public and to facilitate the participation of citizens and businesses into the public decision-making.

Currently, the concept of Good Governance is significantly promoted in the field of public affairs administration. As specified by [21] or [45], Good Governance is the designation for high-quality and properly functioning public administration with an integrated element of subsidiarity, allowing for the participation of the citizens and respecting democratic values 
and the rule of contemporary modern state. The successful implementation of Good Governance concept in the individual countries indices the quality of governance and overall maturity of public administration in the state. However, as stated by [2], Good Governance is an ideal state of government, which is as a whole difficult to achieve.

The article deals with the evaluation of possibilities of the current state of eGovernment and Good Governance development in the European Union member countries and assessing their interrelations. The goal of the presented article is to investigate the relationship between the eGovernment state and public administration maturity based on the correlation and regression analysis of eGovernment indicators and Good Governance indicators (presented by WGI index). In the presented research there are used results obtained by evaluation of eGovernment in EU countries by TOPSIS method [4] and the data provided by the World Bank, see [43], and processed in own research [5]. The goal of the research is supported by the research question: Countries with higher level of eGovernment development also have an advanced Good Governance. To verify the research question, a hypothesis was determined, which is tested in the application part. $\mathrm{H}_{1}$ : There was a statistically significant correlation between the level of public administration (Good Governance Index) and the level of eGovernment (eGovernment index).

\section{$1 \quad$ Problem Formulation}

The evolution of the concept of Good Governance began in the 20th century. The role of the government started to grow in importance as a significant factor of socio-economic development. Good Governance is primarily presented by the World Bank as a requirement of national states to successfully facilitate economic and administrative reforming processes [18].

The interrelation between governance in the country and eGovernment maturity is discussed and supported by many authors, e.g. [22], [26] or [17]; however, there is not much empirical research in this area. According to [30] both concepts are focusing on the improvement of administrative efficiency, quality of public services and democratic participation. eGovernment is considered to be a significant factor of promoting Good Governance [27]. For this reason, eGovernment is the most important part of administrative reforms in the EU countries [11].

The confirmation of the positive impact of eGovernment development on Good Governance is an important issue affecting not only development countries but also the developed countries comprising the EU countries [20]. It has been increasingly recognized that the involvement of eGovernment tools enhance governments' information sharing and interaction with citizens [37]. eGovernment provides the opportunity to transform the public administration towards greater transparency, accountability and anticorruption. eGovernment tools comply with the principles of Good Governance by requiring appropriate organizational structures, new forms of leadership, transformative public and private partnerships, participatory processes and increased accountability.

\subsection{Current Evaluation Approaches of eGovernment Development}

The development of eGovernment is a continuous process of improvement that requires continuous evaluation and updating framework using modern computing technologies and platforms [24]. According to [26] world eGovernment rankings are increasingly important since they guide countries' focus of their efforts. The eGovernment rankings are in a process of maturation in that direction, moving from purely measuring web sites to assessing use and government qualities. 
A large amount of research has been investigated into monitoring, evaluating and benchmarking eGovernment systems [35]. Thus, with the rapid eGovernment development, it becomes critical to investigated, redefine, restructure and also reweight the related eGovernment development frameworks and indices, as stated by [33] or [36]. There is a number of indexes describing eGovernment development. Each model measures how ready a society or economy is to benefit from ICT. However, the range of tools uses widely varying definitions and different methods for measurement [26].

eGovernment has been monitored by many organizations. However the approaches to eGovernment monitoring differ considerably across organizations. E.g. [15] processes and evaluates data in the field of eGovernment by indicators measuring the interaction of citizens and businesses with public administration. [16] uses indicators describing the state of fulfilment of the European Information Policy. OECD also deals with economic analysis of eGovernment, see [29], focusing on the identification of the eGovernment impacts in terms of costs and benefits comparison. In contrary, the European Commission's approach to eGovernment evaluation is connected with the effectiveness of evaluation of the European Information Policy [14]. This activity is based on the obligations of European institutions. For the purpose of the European Information Policy evaluation, there was designed the evaluation framework of basic eServices by the organization Capgemini [7]. These eServices are evaluated annually in the EU. At the international level, the evaluation of selected aspects of eGovernment also deals with benchmarking with UN. There is evaluated the practice and progress of UN member countries in eGovernment. UN [38] deals with the evaluation of eGovernment on the basis of the annual evaluation of "eGovernment Readiness index" and "eParticipation index". In contrast, on the distinction of different levels of "overall maturity scores" of eServices is based on the evaluation of the organization Accenture from 2000, see [1].

\subsection{Good Governance Evaluation Approach}

Due to the fact that Good Governance concept has a relatively short history, there is a large number of projects dedicated to the modern measuring of governance. The outputs of these projects cover a wide portfolio of governance indicators. The beginnings of the application of the governance indicators are in the 80 s of the $20^{\text {th }}$ century, when the qualitative case studies were published emphasizing the importance of governance for socio-economic development, see [28]. The main sponsor of these research projects were organizations such as USAID, IMF, WB, UN or EU.

Approaches to evaluating of individual aspects of the governance are focusing mainly on expert assessment panels that enable comparisons among countries using a variety of indicators. The pioneers of this type of projects became private consulting firms already in the late $70 \mathrm{~s}$ and $80 \mathrm{~s}$ of the $20^{\text {th }}$ century. In academic research, the data for assessment of governance began to be used in recent years, e.g. [9]. Parallel to these commercial activities, as documented by [32], non-profit and academic projects of expert measurement of governance gradually began to be promoted. The most famous is the "Corruption Perception Index of Transparency International". Other projects dealing with the evaluation of governance are e.g. Studies of the World Bank "World Business Environment Survey", an investigation of the University of the United Nations' "World Governance Survey" or the "Transformation Index" by Bertelsmann Foundation and "Global Governance Initiative" of the World Economic Forum, see [10]. Article [8] developed the European Quality of Government Index (EQI). It is based on survey data on corruption and governance in the EU regions in 2010 and 2013. "Institute Aggregate Governance Indicators", a project of the World Bank, represents a very important contribution to the development of Good 
Governance indicators, see [38]. The benefit of Good Governance indicators lies primarily in the fact that they highlighted the key role of Good Governance for successful socio-economic development.

The World Bank has been collecting data about Good Governance for broad international comparison since 1996 and currently they have been monitored annually. It processes indicators of governance for 215 economies of the world, closer [38]. Good Governance is monitored on the basis of six aggregate indicators, so called WGI (Worldwide governance indicators): Voice and Accountability, Political Stability and Absence of Violence, Government Effectiveness, Regulatory Quality, Rule of Law and Control of Corruption. Each of the aggregate indicators becomes normalized values in the interval from -2.5 (worst result) to 2.5 (best result).

\section{$2 \quad$ Research Methodology}

The interdependency between eGovernment and Good Governance development in EU member countries was examined by usage of correlation and regression analysis. Data for investigation of variables interdependence were obtained by former research, see [4]. The data are describing the state of Good Governance and eGovernment in 2013.

The evaluation of the state of Good Governance in EU countries was performed based on the World Bank approach and dates of aggregate indicators of Good Governance for 2013 provided by the World Bank [43]. The state of Good Governance in EU countries was determined on the basis of the above mentioned six aggregate indicators as the arithmetical average, see formula (1)

$$
\overline{\mathrm{x}}=\frac{1}{\mathrm{n}}\left(\mathrm{x}_{1}+\mathrm{x}_{2}+\ldots+\mathrm{x}_{\mathrm{n}}\right)=\frac{1}{\mathrm{n}} \sum_{\mathrm{i}=1}^{\mathrm{n}} \mathrm{x}_{\mathrm{i}}
$$

where $\overline{\mathbf{x}}$ is the Composite Index of Good Governance, $n$ is the number of aggregate indicators and $x_{\mathrm{i}}$ are the results of individual aggregate indicators.

The evaluation of the state of eGovernment was based on the eGovernment evaluation model. The model included nine eGovernment indicators monitored by international institutions (United Nations - UN, European Union and Eurostat). The evaluation was performed using the multiple criteria decision making (MCDM) method - TOPSIS method (The Technique for Order Preference by Similarity to Ideal Solution). The TOPSIS as a MCDM method is a practical tool for selecting and creating a rank of more alternatives, the application of which can be found in various areas of economy. Within the scope of these methods TOPSIS is used as the main decision-making technique in the "Asia Pacific area". Olson [31] sees its use also in manufacture, financial investment, assessment of sports teams, and application of automatized processes. Shih, Shyur, Lee [34] see its use, for example, in water management, in robot selection or facility location selection. Area risk assessment of construction projects and comparison of the regional aircraft parameters are completed by [19]. Vavrek, Kotulič and Adamišin [39] and [40] use this method in public sector to municipal evaluation. According to [34] or [6] the aim of the method is to determine ranking of individual variants in terms of selected criteria, wherein the variant with the best ranking represents the best compromise variant. TOPSIS method is based on the selection of a variant that is closest to the ideal variant and furthest from the baseline variant. It is assumed to be the maximizing character of criteria. Application of TOPSIS method is described in [44] and it consists of 7 steps:

- creation of the criteria data matrix;

- creation of the normalized data matrix; 
- creation of the weight normalized data matrix;

- determination of the ideal and basal variant relative to the matrix values;

- distance calculation of variants from the ideal variant, respectively basal variant;

- calculation of the relative distance indicator of variants from basal variant;

- creation of the ranking of EU countries.

The evaluation is based on data set across multiple data sources. These are "eGovernment Benchmark" study from 2014, see [14], data processed by Eurostat, see [15] and data managed by UN, see [38]. Evaluated data described the state of eGovernment in the year 2013. In the research there was selected the final list of variants (the EU-28 countries) and criteria (9 eGovernment indicators.) The selected eGovernment indicators (i1 - i9) included 3 types of indexes:

- Indexes monitored by European Commission: User Centric Government (i1), Transparent Government (i2); Citizen Mobility (i3), Business Mobility (i4) and Key Enablers (i5);

- indexes monitored by UN: Online Service Index (i6), E-Participation Index (i7);

- indexes monitored by Eurostat: Individuals Using Internet (i8) and Enterprises Using Internet (i9).

These above mentioned outputs of our own research were used as input data for regression analysis examining the correlation between the Good Governance maturity and eGovernment state. The relationship between variables was tested by correlation analysis and regression analysis. In both cases, firstly normal distribution of each variable was tested by Shapiro-Wilk test in formula (2).

$$
\mathrm{W}=\frac{\left(\sum \mathrm{u}_{\mathrm{i}} \mathrm{x}_{\mathrm{i}}\right)^{2}}{\sum \mathrm{u}_{\mathrm{i}}^{2} \sum\left(\mathrm{x}_{\mathrm{i}}-\overline{\mathrm{x}}\right)^{2}}
$$

where $\mathbf{u}_{\mathrm{i}}$ is constant, $\mathbf{x}_{\mathrm{i}}$ is the value of $i$-th statistical unit and $\overline{\mathbf{x}}$ is average of variable.

Linear correlation between TOPSIS evaluation of eGovernment (eGovernment Index) and Good Governance (Composite Index of Good Governance) was tested by Pearson correlation coefficient or Kendall rank coefficient (depends on normal distribution of each variable). Estimation of constant and regression coefficient was realized by Method of Least Squares is described in formula (3)

$$
\sum_{\mathrm{i}=1}^{\mathrm{n}}\left(\mathrm{y}_{\mathrm{i}}-\widehat{\mathrm{y}_{1}}\right)^{2}=\sum_{\mathrm{i}=1}^{\mathrm{n}} \mathrm{e}_{\mathrm{i}}^{2} \rightarrow \min
$$

where $\mathbf{y}_{\mathbf{i}}$ is measured value, $\hat{\mathbf{y}}_{\mathbf{i}}$ is estimated value and $\mathbf{e}_{\mathbf{i}}$ is random error (residue).

Model suitability was assessed by coefficient of determination which is a number that indicates how well the data fit the statistical model, see formula (4)

$$
\mathrm{R}^{2}=\frac{\sum_{\mathrm{i}=1}^{\mathrm{n}}\left(\mathrm{y}_{\mathrm{i}}-\widehat{\mathrm{y}}_{\mathrm{i}}\right)^{2}}{\sum_{\mathrm{i}=1}^{\mathrm{n}}\left(\mathrm{y}_{\mathrm{i}}-\overline{\mathrm{y}}_{\mathrm{i}}\right)^{2}}
$$

where $\mathbf{y}_{\mathbf{i}}$ is measured value, $\hat{\mathbf{y}}_{\mathbf{i}}$ is estimated value and $\overline{\mathbf{y}}_{\mathbf{i}}$ is average value.

All these procedures were realized two times with the original data and also the normalized data. Monitored indicators were normalized according to equation (5)

$$
A_{i-N O R M}=\frac{A_{i}-\overline{A_{1}}}{s_{x_{i}}}
$$


where $\mathrm{A}_{\mathrm{i}-\mathrm{NORM}}$ is normalized value of the indicator $i, \mathbf{A}_{\mathbf{i}}$ is original value of the indicator $i$, $\overline{\mathbf{A}_{\mathbf{1}}}$ is average value of the indicator $i$ and $\mathbf{S}_{\mathbf{x}_{\mathbf{i}}}$ is standard deviation of the indicator $i$.

The data were processed in MS Excel and in the statistical program Statgraphics.

\section{$3 \quad$ Results and Interpretation}

Based on the results of TOPSIS method it was possible to determine the ranking of EU countries in terms of the functioning of eGovernment, see Fig.1 (original data). The detailed calculations are processed in [4]. In Fig. 1, there are also presented the normalized data according to formula (5).

Assessment of the state of eGovernment in the EU countries in 2013 showed that Estonia, Finland and Sweden ranked on the best place, while the worst eGovernment state was detected in Croatia, Bulgaria and Romania.

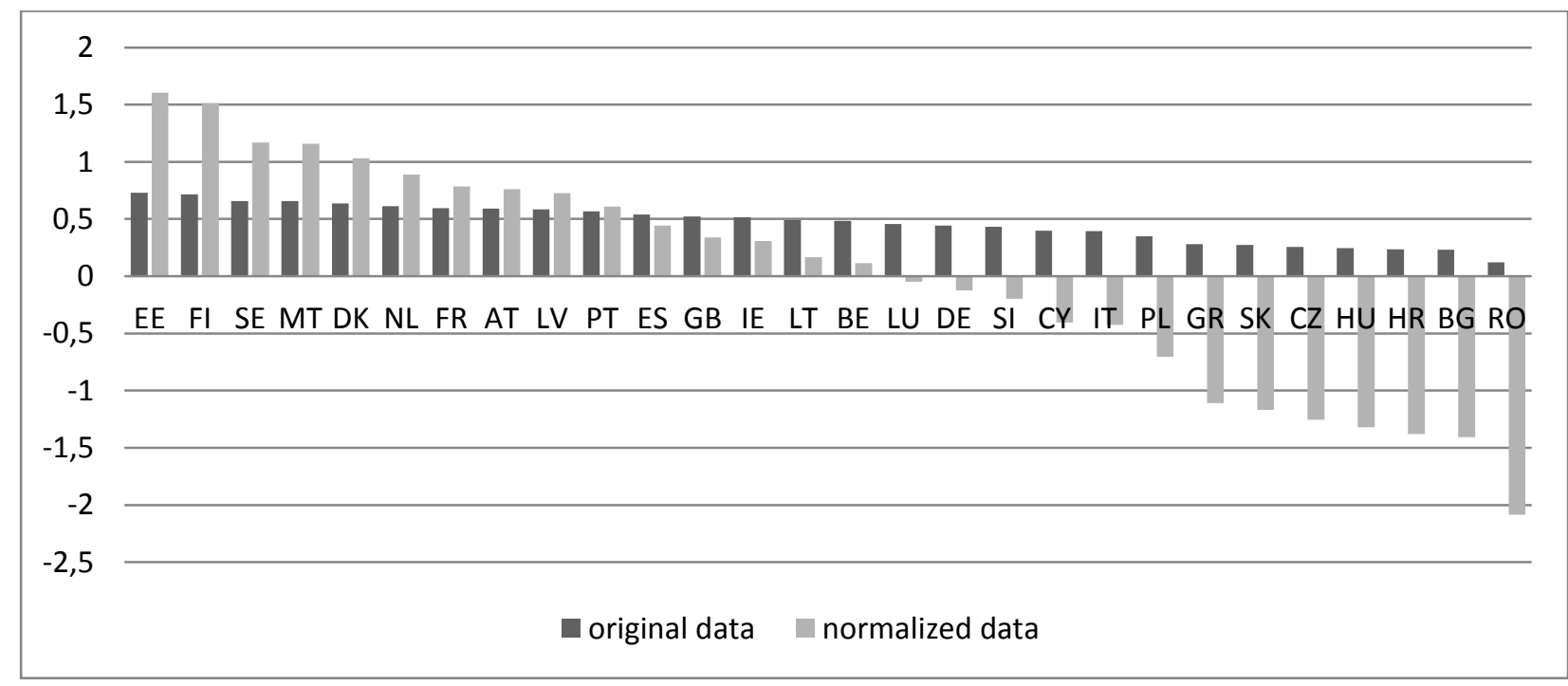

Source: Own calculations based upon data from European Commission (2014), Eurostat (2013) and UNPACS (2014).

Fig. 1: eGovernment evaluation in the EU countries by TOPSIS method in 2013 (eGovernment Index)

Summarized positions of EU countries according to the state of Good Governance (original data) are in Fig. 2. The normalized data are also included in this figure. The obtained results showed that the top ranked countries in EU are the Nordic countries: Finland, Sweden and Denmark. On the contrary, the worst score was reached by Greece, Romania and Bulgaria.

The obtained results of the eGovernment and Good Governance state in EU countries in the year 2013 indicated possible interrelations of both variables (eGovernment Index and Composite Index of Good Governance). The assessment of the relation between the eGovernment and Good Governance development in EU countries was analyzed in the regression model. 


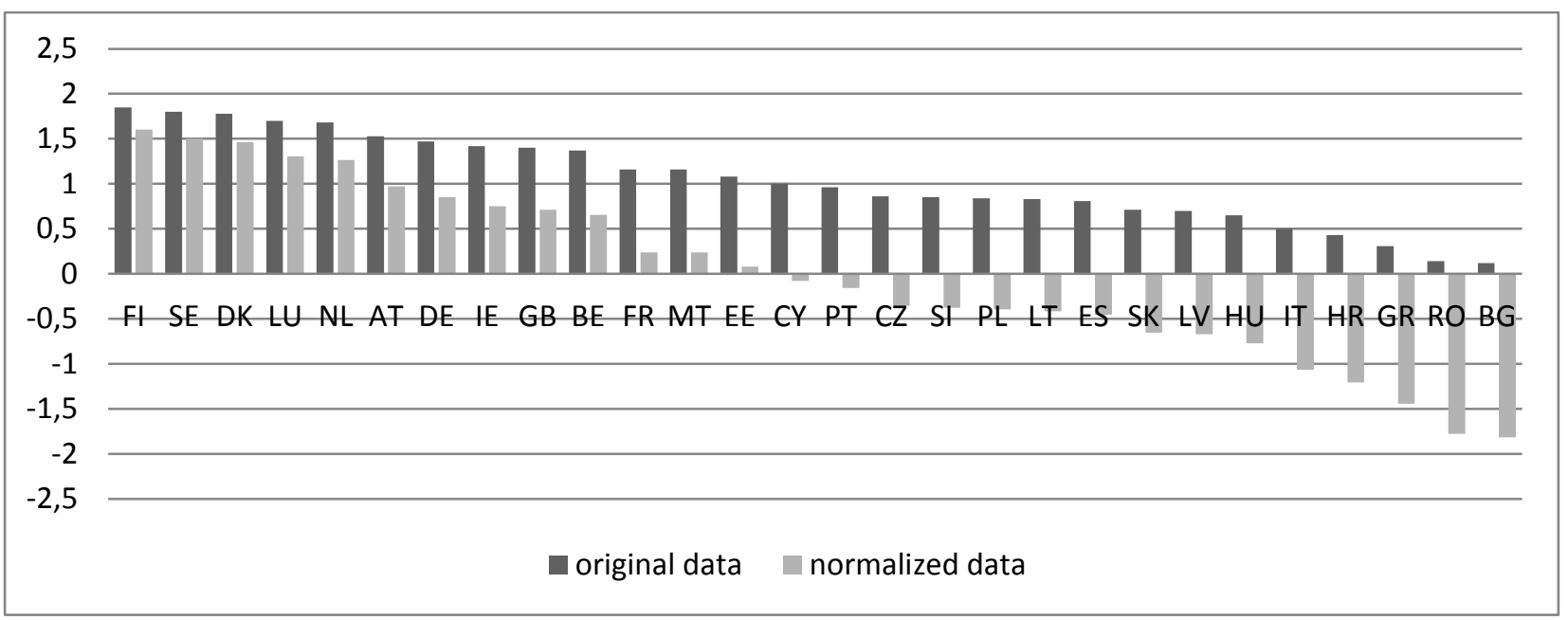

Source: Own calculations based upon data from World Bank (2014)

Fig. 2: Good Governance evaluation in the EU countries in 2013 (Composite Index of Good Governance)

Input data for the verification of research hypothesis were eGovernment Index processed by TOPSIS and Composite Index of Good Governance from 2013. In order to check the relationship (the correlation of these two variables), it was necessary to verify their normal distribution. Results are summarized in Tab.1.

Tab. 1: Normal distribution of variables

\begin{tabular}{|l|c|c|}
\hline Name of index & Original data & Normalized data \\
\hline eGovernment Index & $0.958(0.347)$ & $0.958(0.347)$ \\
\hline Good Governance Index & $0.957(0.331)$ & $0.957(0.331)$ \\
\hline
\end{tabular}

Source: Own calculations

Confirmation of the normal distribution of both variables allowed to test the relationship between these variables using Pearson coefficient, which confirmed their linear correlation (Woriginal $=$ Wnormalized $=0.7503 ; p \leq 0.001$ ). According to Tab. 1 we can confirm that variable normalization does not affect its distribution.

By usage of correlation analysis (Tab. 2 and Tab. 3) we can confirm the null hypothesis, i.e. countries with higher level of Good Governance have also higher level of eGovernment in both case (original and normalized data).

Tab. 2: Linear regression - original data

\begin{tabular}{|l|c|r|c|c|c|}
\hline Source & Sum of Squares & D.f. & Mean Square & F-Ratio & P-Value \\
\hline Model & 0.415261 & 1 & 0.4152610 & 33.49 & 0.0000 \\
\hline Residual & 0.322407 & 26 & 0.0124003 & & \\
\hline Total (Corr.) & 0.737668 & 27 & & & \\
\hline
\end{tabular}

Source: Own calculations

The results of regression model for original data are summarized in Tab. 2 and the results in case of normalized data are in Tab. 3 . 
Tab. 3: Linear regression - normalized data

\begin{tabular}{|l|c|r|c|c|c|}
\hline Source & Sum of Squares & D.f. & Mean Square & F-Ratio & P-Value \\
\hline Model & 15.1992 & 1 & 15.199200 & 33.49 & 0.0000 \\
\hline Residual & 11.8007 & 26 & 0.453872 & & \\
\hline Total (Corr.) & 26.9998 & 27 & & & \\
\hline
\end{tabular}

Source: Own calculations

Tables 2 and 3 capture the significance of regression model that describes the relationship between the monitored variables by means of the following equations (6) and (7):

$$
\text { Good Governance Index }=0.209957+0.245182 * \text { eGovernment Index }
$$

$$
\text { Good Governance Index }=-0.000008738+0.750288 * \text { eGovernment Index }
$$

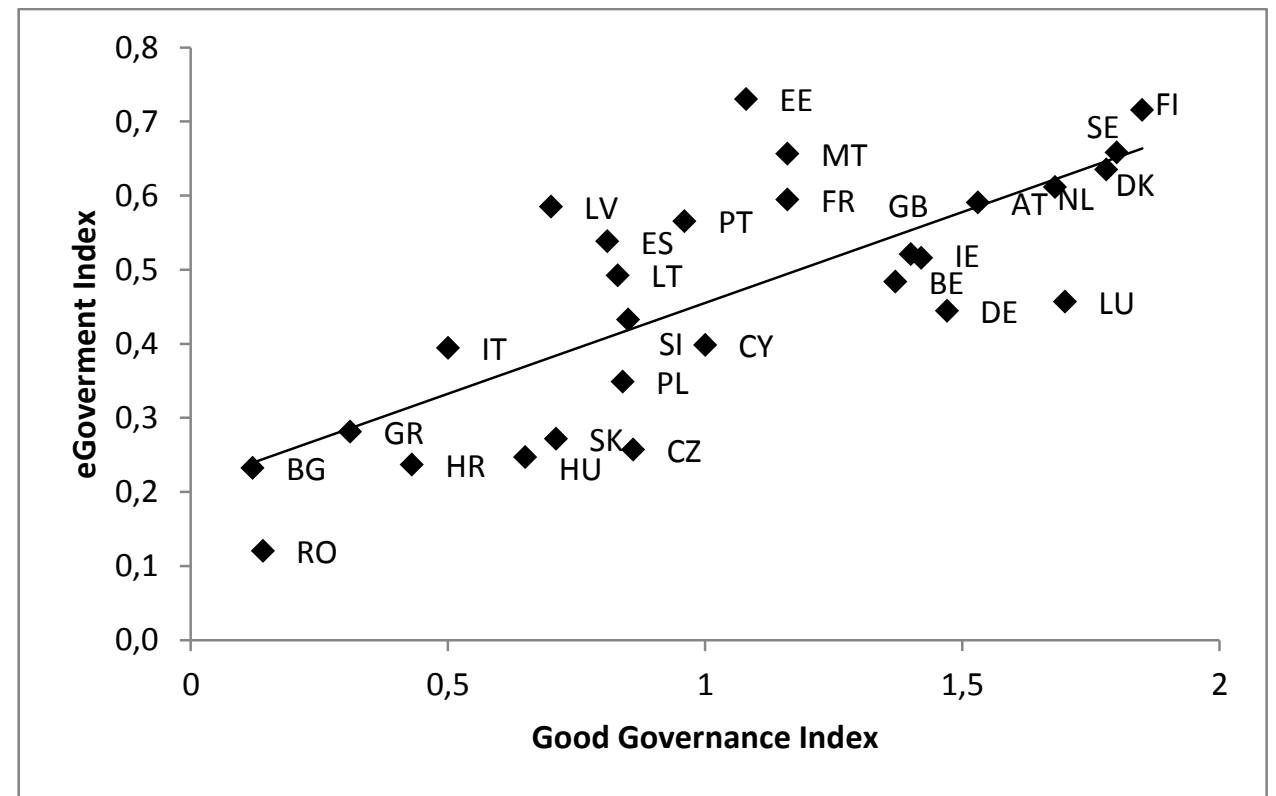

Source: Own elaboration based upon data European Commission (2014), Eurostat (2015), UNPACS (2014) and the World Bank (2014).

Fig. 3: Dependence of Good Governance and eGovernment in EU countries - original data

Coefficient of determination of both regression models $\left(R^{2}=0.5629\right)$ showed the predictive value of regression model. 56.29\% of the eGovernment Index total variability was outlined by above mentioned model. The dependence between Good Governance and eGovernment in EU countries is illustrated in Fig. 3. The result is the same for both original and normalized data, see Fig. 4. 


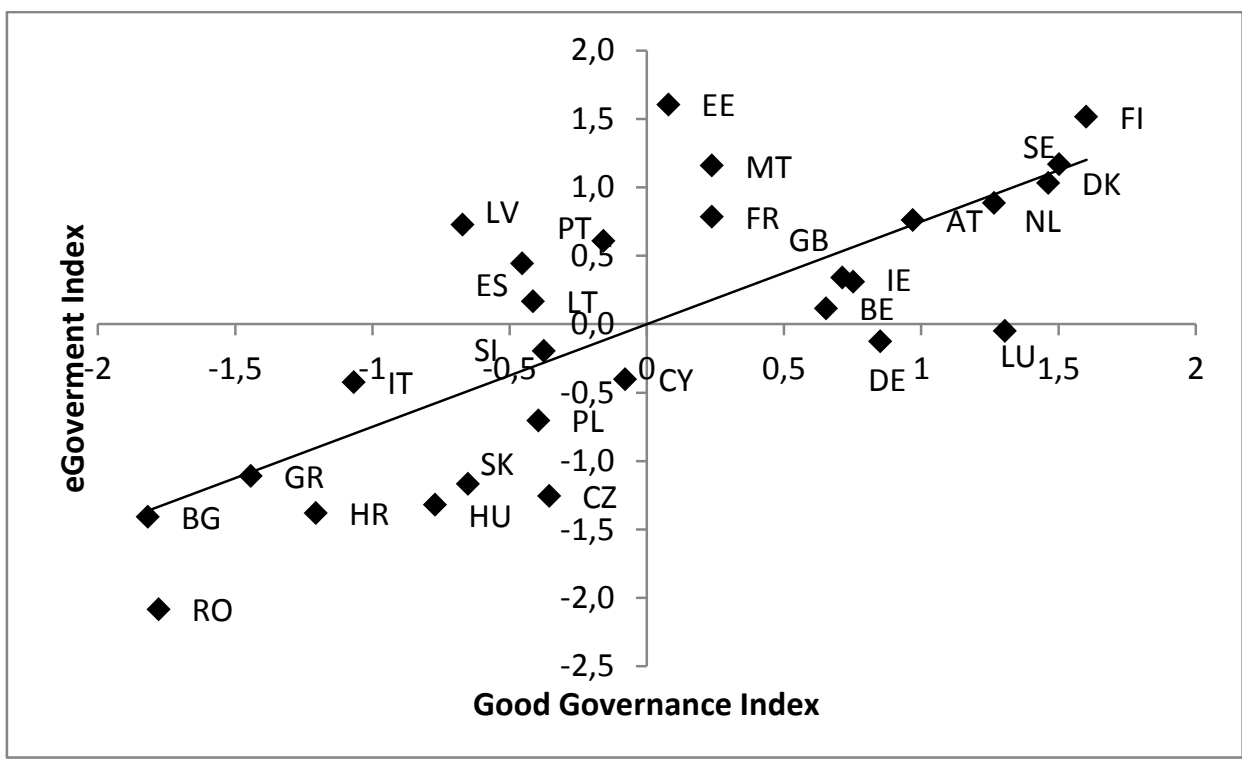

Source: Own elaboration based upon data European Commission (2014), Eurostat (2015), UNPACS (2014) and World Bank (2014).

Fig. 4: Dependence of Good Governance and eGovernment in EU countries - normalized data

\section{Discussion}

The research has confirmed that the state of public administration depends to a large extent on the level of eGovernment in particular countries. The more advanced the level of eGovernment, the higher the level of governance in the country. The dependence between Good Governance and eGovernment was tested in a regression model by usage of eGovernment Index and Good Governance Index. Although both indexes are using different scales (which was the reason for data normalization), this fact didn't affect the resulting arrangement of countries. Similar to our own research, the correlation between eGovernment and Good Governance in relevant countries was approved by [25]. This analysis made across the countries showed correlation with eGovernment development and Good Governance in the case of West Balkans countries.

The results of our own research in the field of eGovernment development also largely reflect the current results of other institutions in this field, such as the European Commission, see [13], [12] or [41]. According to DESI index in the year 2016, see [13], the best position in the dimension of digital public services reach Estonia $\left(1^{\text {st }}\right.$ position - score 0.866$)$, Denmark $\left(2^{\text {nd }}\right.$ position - score 0.808$)$, Finland $\left(3^{\text {rd }}\right.$ position - score 0.789$)$ and Netherlands $\left(4^{\text {th }}\right.$ position score 0.776$)$. The worst ranking in EU countries was reached by Hungary $\left(25^{\text {th }}\right.$ position score 0.396$)$, Slovakia $\left(26^{\text {th }}\right.$ position - score 0.352$)$, Romania $\left(27^{\text {th }}\right.$ position - score 0.335$)$ and Bulgaria $\left(28^{\text {th }}\right.$ position - score 0.331$)$. The Czech Republic is on the $24^{\text {th }}$ position from EU countries (score 0.403). In the year 2014 the position of the Czech Republic was the same ( $24^{\text {th }}$ position) but the score was the worst -0.366 . In case of Slovakia the situation in the year 2014 was better in contrast to the year 2016. In the year 2014 Slovakia reached the $23^{\text {rd }}$ position, the score was 0.368 - better than in 2016. This results of DESI index from 2014 are very similar to results reached in own research. The position of top EU countries corresponds to the conclusions of the research of [41] from the year 2015. According to this research on the $1^{\text {st }}$ position in online services is Estonia and Denmark and on the first position in eParticipation is Estonia and United Kingdom. However in total scores the first three positions are placed by Denmark ( $1^{\text {st }}$ position), United Kingdom $\left(2^{\text {nd }}\right.$ position $)$ and Estonia $\left(3^{\text {rd }}\right.$ position). 
The quality of government in the sense of Good Governance principles was assessed also in all EU member countries. The best state of Good Governance was found out in Finland, Sweden and Denmark. On the worst positions were placed Greece, Romania and Bulgaria. This result is similar to the results of other studies on the quality of government. For example according to [8] on the tree best positions are placed also Denmark, Finland and Sweden. The worst position was found out in the case of Croatia, Bulgaria and Romania.

\section{Conclusion}

The goal of the presented article was to demonstrate the relationship between the eGovernment and Good Governance development. In the research it was confirmed that the level of Good Governance depends on the state of eGovernment in specific countries. The more advanced the level of eGovernment in a country, the higher the level of Good Governance development. The research question was verified. Between the level of eGovernment development and Good Governance development is a positive linear correlation in the case of EU member countries, i.e. countries with higher levels of eGovernment also have higher levels of Good Governance.

According to the realized analysis we can conclude that the heterogeneity of variables does not affect the results of correlation and regression analysis. Pearson coefficient confirmed high correlation between eGovernment Index and Good Governance Index. By usage of regression analysis we can add that this relationship is affected by other variables which are not included in the model.

\section{Acknowledgements}

The article was created within the financial support of the student grant project SGS No. SP2017/129 "Economic Factors Affecting the Ensuring of Public Services with Collective Consumption" on Faculty of Economics, Technical University of Ostrava.

\section{Literature}

[1] ACCENTURE: eGovernment Leadership: Rhetoric vs Reality - Closing the Gap. [online]. 2001. [accessed 2015-07-20]. Available from WWW: http://afyonluoglu.org/PublicWebFiles/eGovBenchmark/ACC/2001-Accenture.pdf

[2] AGERE, S.: Promoting Good Governance: Principles, Practices and Perspectives. Commonwealth Secretariat, London, 2000. ISBN 978-0-85092-629-3.

[3] ALENEZI, H.; TARHINI, A.; SHARMA, S. K.: Development of quantitative model to investigate the strategic relationship between information quality and e-government benefits. Transforming Government: People, Process and Policy. 2015. 9(3), 324-351. ISSN 1750-6166. DOI: 10.1108/TG-01-2015-0004

[4] ARDIELli, E.; HALÁSKOVÁ, M.: Assessment of E-government in EU countries. Scientific Papers of the University of Pardubice. 2015. 22(34), 4-16. ISSN 1211555X.

[5] ARDIELLI, E.; HALÁSKOVÁ, M.: Evaluation of Good Governance in EU countries. Acta academica karviniensia. 2015. 15(3), 5-17. ISSN 1212-415X. DOI: $10.25142 /$ aak.2015.027

[6] BHUTIA, P. W.; PHIPON, R.: Application of AHP and TOPSIS Method for Supplier Selection Problem. Journal of Engineering. 2012. 2(10), 43-50, ISSN 2278-8719. DOI: $\underline{10.9790 / 3021-021034350}$ 
[7] CAPGEMINI: The User Challenge Benchmarking the Supply of Online Public Services. [online]. 2007. [accessed 2015-07-21]. Available from WWW: https://publications.europa.eu/en/publication-detail/-/publication/9b1d1b48-9c1d-453a86a6-9e1caf7b6d98/language-en

[8] CHARRON, N.; DIJKSTRA, L.; LAPUENTE, V.: Mapping the Regional Divide in Europe: A Measure for Assessing Quality of Government in 206 European Regions. Social Indicators Research. 2015. 122(2), 315-346. ISSN 0303-8300. DOI: $10.1007 / \mathrm{s} 11205-014-0702-\mathrm{y}$

[9] CLAGUE, Ch. et al.: Contract-Intensive Money: Contract Enforcement, Property Rights, and Economic Performance. Journal of Economic Growth. 1999. 4(2), 185-211. ISSN 1381-4338. DOI: 10.1023/A:1009854405184

[10] COURT, J.; HYDEN, G.: World Governance Survey: a new approach to assessing governance. [online]. 2003. [accessed 2015-02-12]. Available from WWW: https://www.odi.org/sites/odi.org.uk/files/odi-assets/publications-opinion-files/4084.pdf

[11] HAMMERSCHMID, G.: Decentralisation and Accountability as Focus of Public Administration Modernisation: A Comparative European Perspective. In: Hermann Hill (Hrsg.) Modernizing Government in Europe. pp. 255-271. 2006. ISBN print 978-38329-2799-8. ISBN online 978-3-8452-0343-0. DOI: $10.5771 / 9783845203430-255$

[12] EUROPEAN COMMISSION: EU eGovernment Report 2014 shows that usability of online public services is improving, but not fast. [online]. 2014. [accessed 2016-02-16]. Available from WWW: https://ec.europa.eu/digital-single-market/en/news/euegovernment-report-2014-shows-usability-online-public-services-improving-not-fast

[13] EUROPEAN COMMISSION: The Digital Economy and Society Index (DESI). [online]. 2019. [accessed 2016-09-11]. Available from WWW: https://ec.europa.eu/digitalsingle-market/en/desi

[14] CAPGEMINI: Delivering on the European advantage? - 'How European governments can and should benefit from innovative public services', eGovernment benchmark. 2014. ISBN 978-92-79-38052-5. DOI: 10.2759/4919. ISBN 978-92-79-38051-8. DOI: $10.2759 / 48856$.

[15] EUROSTAT: Statistical database. [online]. 2013. [accessed 2015-02-20]. Available from WWW: https://ec.europa.eu/eurostat/data/database

[16] EUROSTAT. Statistical database. [online]. 2016. [accessed 2015-03-22]. Available from WWW: http://ec.europa.eu/eurostat/data/database?node_code=isoc_ciegi_sat

[17] GRÖNLUND, Å.: Connecting eGovernment to Real Government - The Failure of the UN eParticipation Index. In: Electronic Government. Springer, Berlin Heidelberg, 2011. pp. 26-37. ISBN print 978-3-642-22877-3. ISBN online 978-3-642-22878-0. DOI: $10.1007 / 978-3-642-22878-0 \_3$

[18] HALDENWANG, Ch. Von: Electronic Government (E-Government) and Development. The European Journal of Development Research. 2004. 16(2), 417-432, ISSN 09578811. DOI: $10.1080 / 0957881042000220886$

[19] ZOLFANI, S. H.; ANTUCHEVICIENE, J.: Team Member Selecting Based on AHP and TOPSIS Grey. Inzinerine Ekonomika-Engineering Economics. 2012. 23(4), 425434. ISSN 1392-2785. DOI: 10.5755/j01.ee.23.4.2725 
[20] KETTANI, D.; MOULIN, B.: E-government for Good Governance in developing countries: Empirical Evidence from the eFez Project. Anthem Press, London, 2015. ISBN 978-0-85728-125-8.

[21] KLENK, T.; NULLMEIER, F.: Public Governance als Reforms Strategie. Edition der Hans-Böckler-Stiftung 97. Düsseldorf, 2004. ISBN 3-935145-72-1.

[22] KRISHNAN, S.; TEO, T.; LIM, J.: Electronic Services of eGovernment in the European Union Countries. Scientific Papers of the University of Pardubice. 2010. 15(17), 138150. ISSN 1211-555X.

[23] LNĚNIČKA, M.: E-government Development Index and its Comparison in the EU Member States. Scientific Papers of the University of Pardubice. 2015. 22(34), 75-87. ISSN 1211-555X.

[24] MÁCHOVÁ, R.: An Analytical Hierarchy Process Model for the Evaluation of the Egovernment Development. Scientific Papers of the University of Pardubice. 2015. 22(34), 88-100. ISSN 1211-555X.

[25] MADZOVA, V.; SAJNOSKI, K.; DAVCEV, L.: E-Government as an Efficient Tool towards Good Governance. Balkan Social Science Review. 2013. 1, 157-174, ISSN 1857-8799.

[26] MOHAMMED, F.; IBRAHIM, O.: Refining E-government Readiness Index by Cloud Computing. Jurnal Teknologi. 2013. 65(1), 23-34. ISSN 1979-3405. DOI: $10.11113 /$ jt.v65.1759

[27] NORRIS, P.: Digital divide: Civic engagement, Information Poverty, and the Internet in Democratic Societies. Cambridge University Press, New York, 2001. ISBN 9780521002233.

[28] NORTH, C. D.: Institutions, Institutional Change and Economic Performance. Cambridge University Press, Cambridge, 1991. ISBN 9780521397346.

[29] OECD: OECD E-Government Project - Benefits Realisation Management. [online]. 2006. [accessed 2015-06-25]. Available from WWW: http://www.oecd.org/officialdocuments/publicdisplaydocumentpdf/?cote=GOV/PGC/E GOV(2006)11/REV1\&docLanguage $=$ En

[30] O'CONNELL, K. A.: Computerizing Government: The Next Generation. The American City \& County Journal. 2003. 118(8). ISSN 0149-337X.

[31] OLSON, D. L.: Comparison of Weights in TOPSIS Models. Mathematical and Computer Modelling. 2004. 40(7-8), 721-727, ISSN 0895-7177. DOI: $\underline{10.1016 / \text { j.mcm.2004.10.003 }}$

[32] POTU゚ČEK, M. et al.: Strategické vládnutí a Česká republika. Grada, a.s., Praha, 2007. ISBN 978-80-247-2126-2.

[33] RORISSA, A.; DEMISSIE, D.; PARDO, T.: Benchmarking e-Government: A comparison of frameworks for computing e-Government index and ranking. Government Information Quarterly. 2011. 28(3), 354-362. ISSN 0740-624X. DOI: $10.1016 /$ j.giq.2010.09.006

[34] SHIH, H.-S.; SHYUR, H.-J.; LEE, E. S.: An extension of TOPSIS for group decision making. Mathematical and Computer Modelling. 2007. 45(7-8), 801-813. ISSN 08957177. DOI: $\underline{10.1016 / j . m c m .2006 .03 .023 ~}$ 
[35] PRADA, L. T.; PINA, V.; ROYO, S.: E-government and the transformation of public administrations in EU countries: Beyond NPM or just a second wave of reforms? University of Zaragoza, Zaragoza, 2005. DOI: 10.1108/14684520510628918 [online]. [accessed 2015-03-22]. Available from WWW: http://www.dteconz.unizar.es/DT2005$\underline{01 . p d f}$

[36] UNITED NATIONS: United Nations E-Government Survey 2014. [online]. 2014. [accessed 2016-08-02]. Available from https://publicadministration.un.org/egovkb/en-us/Reports/UN-E-Government-Survey$\underline{2014}$

[37] UNITED NATIONS. Responsive and Accountable Public Governance. ISBN 978-92-1123196-0. [online]. 2015. [accessed 2016-09-22]. Available from WWW: http://workspace.unpan.org/sites/Internet/Documents/UNPAN95253.pdf

[38] UNITED NATIONS: UN Data Center - E-Government Development Index. [online]. 2014. [accessed 2016- 08-02]. Available from WWW: http://unpan3.un.org/egovkb/enus/Data-Center

[39] VAVREK, R.; KOTULIČ, R.; ADAMIŠIN, P.: Topsis Method and Its Application to the Local Self-Government of the Slovak Republic. Journal of Applied Economic Sciences. 2014. 9(3), 504-512. ISSN 18436110.

[40] VAVREK, R., KOTULIČ, R.; ADAMIŠIN, P.: Evaluation of Municipalities Management with the Topsis Technique Emphasising on the Impact of Weights of Established Criteria. Lex localis - Journal of Local Self-Government. 2015. 13(2), 249264. ISSN 1581-5374. DOI: $10.4335 / 249-264(2015)$

[41] WASEDA UNIVERSITY: IAC International E-Government Ranking Survey. [online]. 2015. [accessed 2018-10-02]. Available from WWW: http://www.egov.waseda.ac.jp/pdf/2015_Waseda_IAC_E-Government_Press_Release.pdf

[42] WEST, D. M.: E-Government and the Transformation of Service Delivery and Citizen Attitudes. Public Administration Review. 2004. 64(1), 15-27. ISSN 0033-3352. DOI: $10.1111 / \mathrm{j} .1540-6210.2004 .00343 . \mathrm{x}$

[43] WORLD BANK: Worldwide Governance Indicators. [online]. 2014. [accessed 201604-05]. Available from

WWW: http://info.worldbank.org/governance/wgi/index.aspx\#home

[44] YOON, K. P.; HWANG, Ch.: Multiple Attribute Decision Making: An Introduction. Sage, California, 1995. ISBN 9780803954861.

[45] ZANGER, S. C.: Good Governance and European Aid: The Impact of Political Conditionality. European Union Politics. 2000. 1(3), 293-317. ISSN 1741-2757. DOI: $10.1177 / 1465116500001003002$

Ing. Eva Ardielli, Ph.D.; Ing. Roman Vavrek, Ph.D. 
Dobrá správa věcí veřejných (Good Governance) je současný trend ve veřejné správě na celém světě. Zdůrazňuje efektivitu, otevřenost a transparentnost v ř́zení veřejných záležitostí. Důležitým faktorem dobré správy je aplikace ICT ve veřejné správě a rozširrování eGovernmentu jako progresivního prvku modernizace veřejné správy. Př́íspěvek je zaměřen na zhodnocení vzájemné závislosti mezi eGovernmentem a rozvojem Good Governance v zemích Evropské unie (EU). Vzájemná závislost proměnných je zkoumána na základě hodnocení eGovernmentu pomocí metod multikriteriálního rozhodování (metoda TOPSIS) na základě hodnot indexu WGI sledovaného a zpracovávaného Světovou bankou. Na základě využití korelační a regresní analýzy byla potvrzena vzájemná závislost mezi eGovernmentem a rozvojem Good Governance v členských zemích EU.

\section{BEWERTUNG DER EGOVERNMENT UND GOOD GOVERNANCE ENTWICKLUNG IN DEN MITGLIEDSTAATEN DER EU}

Good Governance ist ein aktueller Trend in der öffentlichen Verwaltung weltweit. Dieser Trend betont Effizienz, Offenheit und Transparenz im Public-Affairs-Management. Ein wichtiger Faktor für Good Governance ist die Anwendung von ICT in der öffentlichen Verwaltung und die Ausweitung von e-Government als fortschrittlichem Element der Modernisierung der öffentlichen Verwaltung. Der Artikel befasst sich mit der Bewertung der Interdependenz zwischen e-Government und Good Governance in den Ländern der Europäischen Union (EU). Die Abhängigkeit der Variablen wird auf der Grundlage der EGovernment-Bewertung unter Verwendung von Entscheidungsverfahren mit mehreren Kriterien (TOPSIS-Methode) untersucht, die auf WGI-Indexwerten basieren, die von der Weltbank überwacht und verarbeitet werden. Basierend auf der Korrelations- und Regressionsanalyse wurde die Interdependenz zwischen e-Government und der Entwicklung von Good Governance in den EU-Mitgliedstaaten bestätigt.

\section{OCENA ROZWOJU EGOVERNMENT I DOBREGO RZĄDZENIA W KRAJACH CZŁONKOWSKICH UE}

Dobre rządzenie (Good Governance) to aktualny trend w administracji publicznej na całym świecie. Trend ten podkreśla skuteczność, otwartość i przejrzystość w zarządzaniu sprawami publicznymi. Ważnym czynnikiem dobrego rządzenia jest stosowanie ICT $\mathrm{w}$ administracji publicznej oraz rozwój e-administracji jako postępowego elementu modernizacji administracji publicznej. Artykuł skupia się na ocenie współzależności pomiędzy administracją elektroniczną a rozwojem dobrego rządzenia w krajach Unii Europejskiej (UE). Współzależność zmiennych jest badana na podstawie oceny eGovernment przy użyciu metod wielokryterialnego podejmowania decyzji (metoda TOPSIS) w oparciu o wartości wskaźnika WGI badanego i opracowywanego przez Bank Światowy. Na podstawie analizy korelacji i regresji potwierdzono współzależność między administracją elektroniczną a rozwojem dobrego rządzenia w państwach członkowskich UE. 